\title{
Review
}

\section{Michael Oakeshott and the conversation of modern political thought}

\author{
Luke Philip Plotica \\ SUNY Press, New York, 2015, 224pp., ISBN: 978-1438455358
}

Contemporary Political Theory (2016) 15, e37-e40. doi:10.1057/cpt.2015.46;

published online 6 October 2015

Plotica has performed a major service by writing a book that shows in measured and careful fashion how Oakeshott's work relates to several of the major schools of thought that have formed the current landscape of political ideas as it has developed since the mid-twentieth century. This is an important contribution not least because Oakeshott's major published works rarely addressed his contemporaries directly. Rationalism in Politics (1962) and On Human Conduct (1975), the two books on which his reputation as a political philosopher was mostly built, were almost devoid of references to any but the most canonical political thinkers.

In developing the theory of civil association in On Human Conduct in particular, Oakeshott explicitly presented himself as directly engaging the work of Aristotle, Hobbes and Hegel. This approach created the impression of someone profoundly out of sympathy with his own era to the point of idiosyncrasy, making it difficult for many to understand why his work was worth paying attention to at all. Some of the subsequent scholarship, although admiring, ended up reinforcing this picture. For example, Coat's (2000) book Oakeshott and His Contemporaries, encouraged the impression of a writer with little connection to modernity by identifying Oakeshott's contemporaries with kindred spirits in the history of political thought such as St Augustine and Montaigne.

Plotica sees his book as a kind of successor to Coats's work insofar as he too aims to relate Oakeshott's ideas to those of a number of other thinkers, but he wants to rescue Oakeshott from the position of relative isolation that it would be fair to say he still occupies. Plotica is firmly convinced that although Oakeshott often lacks a common vocabulary with influential contemporary traditions of political theory such as communitarianism, post-structuralism, democratic theory and liberal pluralism, he has plenty to offer theorists in all of these areas.

Plotica begins with a consideration of the affinities between the Oakeshottian notions of a tradition and a practice and the Wittgensteinian concept of a language-game first observed by Pitkin in Wittgenstein and Justice (1972). A common misconception that

(C) 2016 Macmillan Publishers Ltd. 1470-8914 Contemporary Political Theory Vol. 15, 3, e37-e40 
arose following the linguistic turn that dominated political theory in the 1950s and the 1960s, Plotica rightly argues, was that the dependency of the individual on a larger social context implied a rigid conservatism. In fact, both Oakeshott and Wittgenstein occupied a 'middle position' according to which individuals are neither 'radically detached' from the practices of their society, nor 'strictly determined' by them (p. 33).

This strategy of showing how Oakeshott persistently managed to split the difference between opposing groups of ideas is pursued to good effect throughout the rest of the book. Plotica's discussion of the communitarianism of Alasdair MacIntyre and Charles Taylor exposes the difference between their account of tradition, which verges on being fully constitutive of individuality, from Oakeshott's, in which tradition is as much created by the individual as vice versa. Like MacIntyre and Taylor, Oakeshott thought of tradition as an indispensable resource for moral and political conduct, but his own account 'reflects a greater valuation of agency' (p. 57).

This valuation was rooted in turn in Oakeshott's powerful sense of the contingency of both tradition and individuality. An emphasis on the inherent historicity of the human condition meant that he could regard nothing as given: traditions only found their existence in the interpretations they were given by the people who took them up. Plotica argues that Oakeshott's account of contingency is 'richer' than that offered by Rorty (1989), whose Contingency, Irony, and Solidarity was itself, as he says, partly inspired by Oakeshott, because Oakeshott appreciates the positive role of what for Rorty appears simply as a brute fact (p. 60). The fact of contingency for Oakeshott means that we hold our fate at least partly in our own hands: we are not simply the puppets of a causally deterministic or otherwise teleologically pre-ordained historical process.

Perhaps the most interesting portion of the book for many readers will be the third chapter, in which, after laying out Oakeshott's debt to Hobbes, Plotica sets out the relationship between his theory of civil association and Foucault's genealogy of the modern state. The idea that a radical left-wing post-structuralist and an English conservative could have anything in common will seem counter-intuitive to many, but Plotica's whole book is devoted to dismantling these convenient labels in favour of detailed conceptual comparisons.

Civil association for Oakeshott was a relationship in terms of the rule of law, which he contrasted with relationship in terms of a common purpose, a connection to which he gave the name 'enterprise association'. Society contains many forms of enterprise association, whether economic, religious or educational, and it is very important to understand that Oakeshott did not think that relationships to others in terms of shared goals and purposes were bad in themselves. Quite the opposite: being able to choose what purposes to pursue was essential to the free exercise of individuality.

What Oakeshott objected to was being forced by the state to participate in enterprises one had not chosen for oneself. The enterprise state had taken many forms in modernity that completely cut across the distinction between 'left' and 
'right' in politics: the neo-liberal capitalist state, the colonial and imperial state, the communist state, the evangelical conversionary state and the fascist or Nazi state were all forms of enterprise association that imposed a single overriding purpose upon their citizens.

Plotica thus reads Foucault through an Oakeshottian lens as a critic of enterprise association, for whom the modern state 'has more and more come to manage society understood as the household, workshop, or market' (p. 83). He also points out the similarity between Foucault's genealogical critique of many of the practices of modern government and Oakeshott's attack on rationalism, the tendency to treat all political problems as technical difficulties for which appropriately scientific solutions can be found. Without denying the many differences between them, Plotica makes clear that 'Oakeshott was himself robustly critical of liberalism in terms that Foucault understood and shared' (p. 87).

This argument might have been made even stronger if Plotica had acknowledged Oakeshott's own youthful roots in a romantic strain of English socialism; this always made his subsequent relationship to 'left' thought much closer than has generally been recognized. Nevertheless, Plotica's detailed comparison is novel and welcome. The commitment to ethical and political pluralism that Oakeshott shares with Foucault, he argues in the remainder of what is the longest chapter in the book, also united him with Isaiah Berlin and Hannah Arendt, figures with whom Oakeshott had at least a passing engagement in his own lifetime.

The final chapter is given over to the consideration of Oakeshott's relationship to democratic theory. Here Plotica relies heavily on 'The Voice of Poetry in the Conversation in Mankind', Oakeshott's major statement on aesthetics, and the use of the analogy of conversation as an ideal for democratic politics to approximate that it alludes to more or less in passing. As Plotica acknowledges, Oakeshott regarded most contemporary thought on democracy as hopelessly confused because of its failure to distinguish democracy as a legitimate constitutional form from the pursuit of populist policies that were likely to win general approval.

For Plotica, Oakeshott has more in common with 'agonal' theorists of democracy like Chantal Mouffe than with the deliberative democratic theory of Habermas, because he does not make truth or consensus either primary or exclusive goals of political life. Indeed, Plotica wisely observes that 'where demonstration and truth are at stake, and politics are pursued as argument, power relations are at their thickest and most sedimented' (p. 136). Oakeshottian democratic politics is more a matter of keeping things going peacefully than of winning the argument or being proved right, and is consequently more attractive, Plotica feels, than theories that portray democracy as ideally an attempt 'to arrive at consensual decisions that have a superior epistemic character' (p. 127). Though well meaning, such ideas are rationalist illusions, and as such are prone to terrible revenge effects.

Plotica is not blind to Oakeshott's faults, and he sometimes reproves him, for example, for making 'the politics of civil association ... somewhat too civil, elevated 
above the agonistic fray' (p. 123). But on the whole he sets out to champion Oakeshott's ideas as more satisfactory than those of the other writers he discusses, without ever being dogmatic in his approach. His knowledge of both Oakeshott and contemporary political theory is deep and sound, and readers of Michael Oakeshott and the Conversation of Modern Political Thought are guaranteed to find in it something worthy of reflection, whether they are primarily interested in Oakeshott and want to discover more about his place in the contemporary scene, or identify with one of the many schools of thought he discusses but find themselves wondering what Oakeshott might have to offer.

\section{References}

Coat, W.J. (2000) Oakeshott and His Contemporaries. Selinsgrove, PA: Susquehanna University Press. Oakeshott, M. (1962) Rationalism in Politics and other Essays. London: Metheun.

Oakeshott, M. (1975) On Human Conduct. Oxford: Oxford University Press.

Pitkin, H. (1972) Wittgenstein and Justice. Berkeley, CA: University of California Press.

Rorty, R. (1989) Contingency, Irony, and Solidarity. Cambridge, UK: Cambridge University Press.

Luke O'Sullivan

National University of Singapore, Singapore 119077

polldo@nus.edu.sg 